\title{
PAID WORK AND RELATIONSHIPS: MAXIMISING THE BENEFITS AND MINIMISING THE LOSSES
}

\author{
Mervyl McPherson
}

\author{
EEO Trust
}

\begin{abstract}
The relationship between paid work and personal relationships operates in both directions, and can be both positive and negative. These interactions and outcomes have implications for society and political economy as well as for individuals and employers. This paper explores the issues through findings from an online survey in New Zealand, together with interviews with New Zealand relationship counsellors, analysis of existing statistics, and a review of previous research internationally. It concludes with recommendations for workplace initiatives to enhance the benefits of personal relationships and minimise the negative impacts.
\end{abstract}

\section{Introduction}

Changes in patterns of work and social changes see men and women trying to combine paid and unpaid work in a different way from previous generations, often with a negative impact on both personal relationships and paid work (Pocock, 2001; Johnston, 2003). The EEO Trust survey on paid work and personal relationships (McPherson, 2004a) and interviews with local relationship counsellors confirm this also appears to be the case in New Zealand. The issues extend beyond long hours to include other factors such as frequent travel, irregular and unpredictable hours, and work intensity which interfere with the need for time together free of work interruptions (including psychologically having the mind still on work so not really being present and available when with a partner) in order to have quality personal relationships (Pritchard, 2002; Russell and Bourke, 2000; Crouter et al, 2001; NZCTU, 2002; Weston et al, 2003).

The relationship between paid work and personal relationships is not unidirectional, however, nor is it only negative. Paid work can have both positive and negative effects on personal relationships. On the other hand, personal relationships can have both positive and negative effects on the workplace. This paper outlines these diverse interactions between paid work and personal relationships, and the importance of this for individuals, their families and their employers, and society. It concludes with suggestions for workplace improvements to enhance personal relationships and hence the wellbeing of individuals, families, business and society.

\section{Changes in Work and Relationships}

\section{Long Hours}

Just over one in three NZ workers, and nearly half of all $\mathrm{NZ}$ men, are working more than 40 hours per week:

\footnotetext{
- $35 \%$ of all workers

- $48 \%$ of men

- $19 \%$ of women
}

Long hours occur at both ends of occupational scale (Figure 1). Professional, managerial and technical workers, and trades and manufacturing workers are more likely than clerical, sales and service workers to report more than forty hours per week.

(Statistics New Zealand, 2003, Table 7.03)

Figure 1

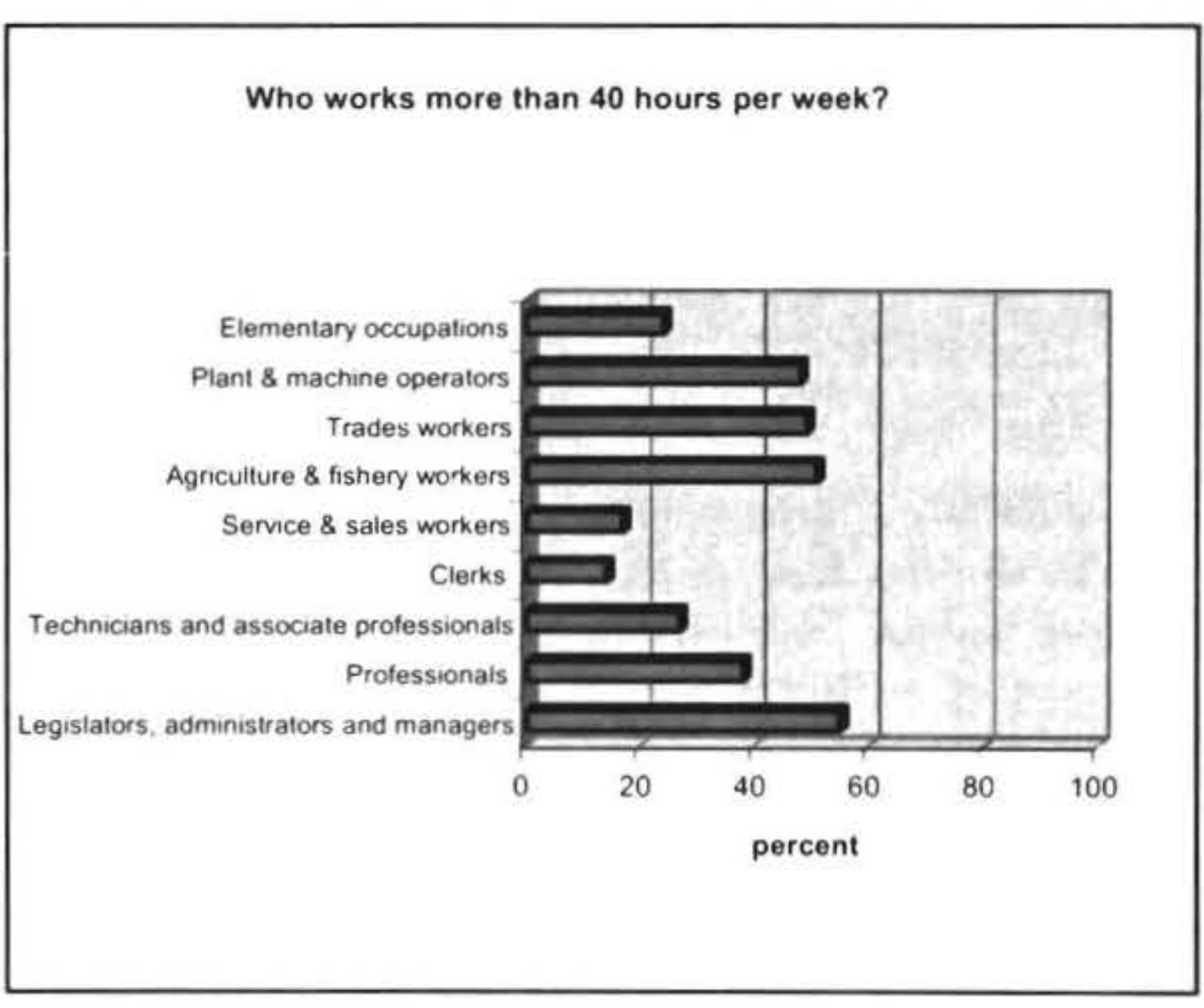

Source: Statistics New Zealand, Labour market Statistics 2003, Table 7.08, from Household Labour Force Survey.

\section{From Breadwinner Couple to Dual Income Couple}

In 2001 only $8 \%$ of adults in the main workforce ages (15-64 years) lived in a traditional breadwinner couple where the man was in full-time work and the woman was not in the labour force at all. Yet this is the model that prevailed when the 40 hour week was instituted in NZ in the 1940s by the first Labour government: 
- In $194589 \%$ of married women were engaged fulltime in domestic duties.

- In 1951 only $8 \%$ of married women were also in paid work.

Figure 2: Work and Relationship Patterns, Ages 15-64, 2001

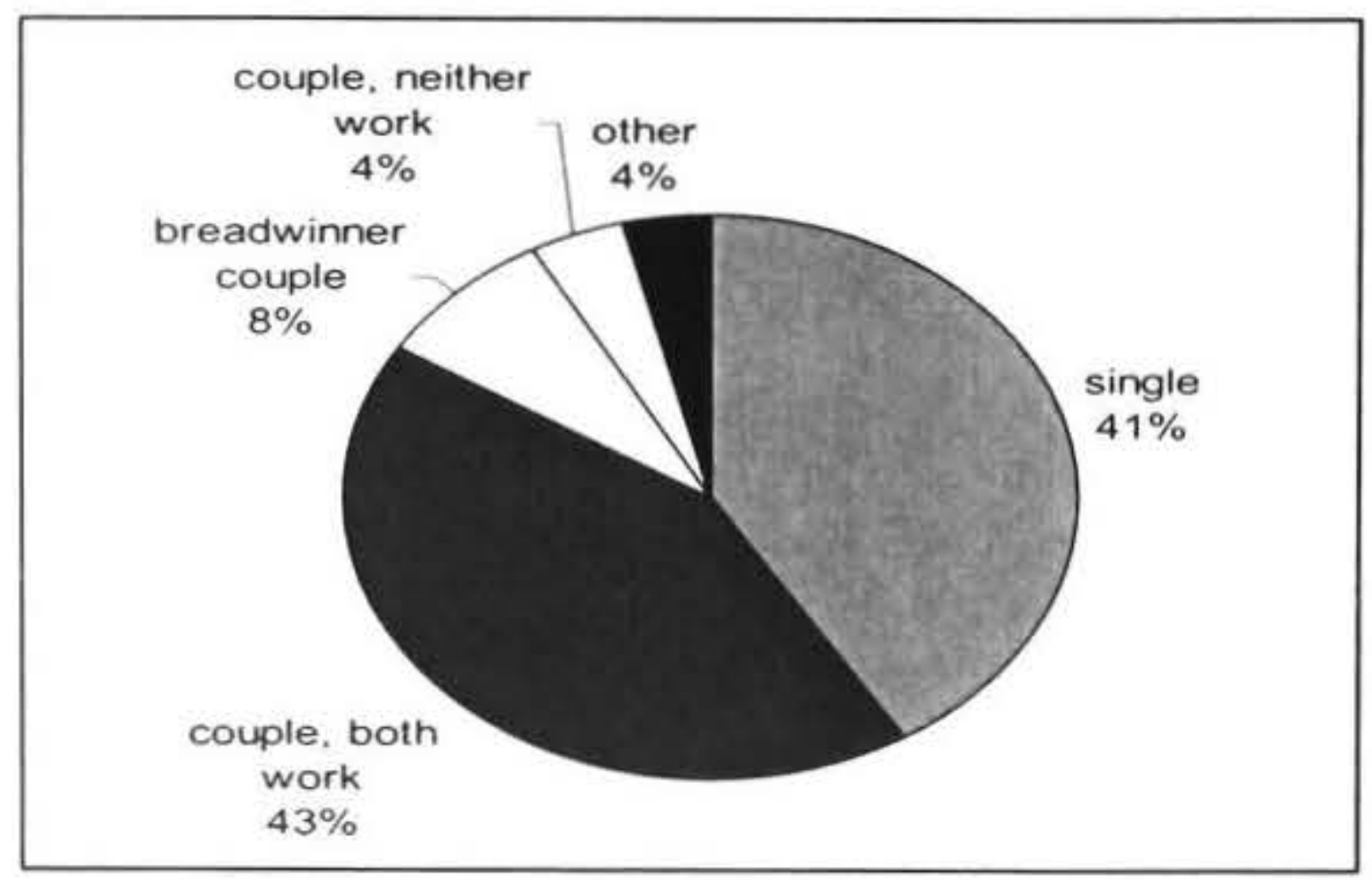

Compare that with today. In 2001, census data show that more than two in five people live in couples where both work, and half of these both work full-time (Figure 2).

It is difficult for anyone today, single or married, with or without children, to combine work and life on the basis of traditional workplace hours and priorities dating from the time of the "male breadwinner and female domestic/caregiver" model which no longer exists for the majority of workers. Not only are individuals working longer hours, but there is no one at home full-time doing the unpaid work, so the total "work" hours (paid + unpaid) have increased beyond the sometimes relatively small increases in paid work hours for an individual. As one New Zealand relationship counsellor put it:

"Everyone is just exhausted" . For couples with young children tensions between the partners result from either rring to manage both couples in paid work - - or from the financial pressures that arise from reduced labour force participation. (McPherson, 2004a)

\section{EEO Trust Survey on Personal Relationships and Paid Work}

The EEO Trust carried out an online survey into paid work and personal relationships earlier this year (McPherson, 2004a). Personal relationships included couple relationships and friendships.

The non-random sampling on-line survey method employed for this survey imposes limitations on the generalisability of these findings to the New Zealand population. However, we do know our biases: whitecollar occupations, women, those aged under 50 years of age, and those working over 40 hours a week are overrepresented. All of these groups make up a substantial part of New Zealand's workforce. With the exception of those in white collar occupations, who are likely to have more access to the internet (Statistics New Zealand, 2001) and thus an on-line survey, their overrepresentation in our sample suggests they may be the groups most concerned about the impact of paid work on their relationships with spouse/partners and friends. We know from the literature and previous qualitative New Zealand research that this is also an issue for those in other occupation groups who are underrepresented in this sample, largely as a consequence of the survey administration method employed.

Lack of work and income affects self esteem and financial status and consequently ability to form and sustain intimate relationships. Australian data show that there is a correlation between men not being in full-time work and not being married/having children (Horin, 2003). This survey found that for four out of five people, paid work has positive effects on relationships, and that many workplaces do value and support their employees' relationships (McPherson, 2004a).

Table 1: Sample Characteristics

\begin{tabular}{|l|c|c|}
\hline & $\begin{array}{c}\text { Sample } \\
(\mathbf{n - 1 3 2 4})\end{array}$ & $\begin{array}{c}\text { NZ } \\
\text { Population } \\
\mathbf{1 5 - 6 4} \\
\mathbf{\%}\end{array}$ \\
\hline Male & 34 & 49 \\
\hline Female & 66 & 51 \\
\hline $\mathbf{1 5 - 3 0}$ & 38 & 31 \\
\hline $\mathbf{3 0 - 4 9}$ & 51 & 46 \\
\hline $\mathbf{5 0 - 6 4}$ & 11 & 23 \\
\hline Professional/managerial & 51 & 26 \\
\hline Technical & 10 & 11 \\
\hline Clerical/sales/service & 25 & 27 \\
\hline $\begin{array}{l}\text { Trades/production/manu- } \\
\text { facturing/ag\&fish/labouring }\end{array}$ & 6 & 31 \\
\hline Other & 7 & 5 \\
\hline Unemployed & 0.5 & 5.1 \\
\hline Don't do paid work & 1.5 & 24 \\
\hline $\begin{array}{l}\text { Work more than 40 hours } \\
\text { per week }\end{array}$ & 44 & 35 \\
\hline
\end{tabular}

\section{Why Relationships are Important, and Who for Individuals}

Relationships with friends, family, partners and workmates are important to individual health and well being and a buffer to stress (Russell and Bourke, 2000; Pocock, 2001). The 1997 US National Study of the Changing Workforce found that married employees have less time for themselves than 20 years ago and this is associated with lower personal wellbeing (Pocock, 2001). A UK study found growing evidence from longitudinal studies that having a supportive close relationship is related to living longer and less psychological distress (Russell and Bourke, 2000). Another US study cited by Russell and Bourke found that higher quality marital relationships can buffer the negative stress effects of job demands for fulltime employed dual-earner couples. 


\section{For Society}

The establishment and maintenance of personal relationships is important to the health, wellbeing and continuance of society (Russell and Bourke, 2000; Pocock, 2001). In the long term macro-social perspective, socialising and the formation of friendships is a precursor to the formation of couple relationships which have the potential to create and raise children. Without this series of social reproduction events, there would not be any future workforce or consumers. Personal relationships and the workplace/market place are interdependent. (Pocock, 2001; Harker, 2003; Matz, 2003). Yet the culture of the modern workplace can be "implicitly hostile to notions that people should lead full and productive lives outside the workplace" (Harker, 2003:10). According to Harker, work-life issues are perceived as the individual's responsibility and there has been little challenge to the overwork culture.

There has been a decline in the forming of partnerships, either legal or de facto, since the 1970s (McPherson, 1995). While this is not necessarily a consequence of changes in the workplace, attempts by women to balance paid work and family have resulted in entrenchment of low fertility, to sub-replacement levels, in New Zealand, many European and other western countries and Japan. Fertility levels in New Zealand are clearly inversely linked to occupational level, with women in professional and managerial occupations, particularly those who are full-time, being less likely to have children, or having fewer children than those in other occupational groups (Sceats, 2003:162, table7). This is consistent with it being women in urban areas who are having low rates of childbearing. With fertility levels declining there is a need for us as a society to rebalance priorities and reform the relationship between work and family.

While Maori, Pacific and other non-European cultures are believed to traditionally place higher priority on relationships, living in a post-industrial society means they also are faced with the economic reality of the importance of paid work for their survival, and the inherent conflict between time spend in paid work and family time.

\section{For Families}

Relationships are the key to family formation and survival. According to Australian work-family researcher Graeme Russell, the most important thing fathers can do for their children is to pay attention to the relationship with their partner (Russell, 2003). [That could apply whether the couple is co-resident or in separate households.]

Workload commitments are a major barrier to being involved in relationships and parenting by fathers. Over half $(53 \%)$ of those Russell surveyed in Australia $(n=3977)$ said that job and family life interfered with each other and they would prefer to work 10 hours less than the current 47 hours per week average. Strengthening relationships and families today will have long-term intergenerational positive impact on all levels of society.

\section{For Employers/Organisations}

The current labour market climate is one of skill shortages where demand for good employees exceeds supply (Department of Labour, 2003). In order to be an employer of choice and maximise their chances of attracting and retaining the staff they need, organisations are having to meet potential and current employees' needs or desires for work-life balance (Saunders, 2004). This includes the need to implement policies and initiatives that recognise the need for and allow employees to establish and maintain good personal relationships with their spouse/partner, friends and workmates/colleagues. For example, younger workers, both men and women, are likely to turn down job offers, transfers, or promotions that would have a negative impact on their partner's career or on their relationship in general (McPherson, 2004a; Russell and Bourke, 2000).

Apart from this supply/demand market imperative, there are a number of other benefits to employers of recognising the importance of workers maintaining good personal relationships. The literature on paid work and personal relationships refers to the impact good personal relationships have on workplace productivity as "positive spillover" or "home-work synergy" (Straw, 2000).

Interpersonal skills are important in the workplace for relationships between workers, between workers and managers, and between workers and customers, but general relationship skills are learnt from relationships outside the workplace. Where people have problems in their personal relationships, the skills taught in relationship counselling are the same as those needed in the workplace - communication, conflict resolution, negotiation, leading by example, role modelling, positive reinforcement, and authoritative not authoritarian leadership (Straw, 2000). Time spent attending counselling sessions to improve personal relationship skills is therefore not a cost, but a benefit to an employer or organisation.

Conversely, relationship training in the workplace is likely to have a positive spillover effect on personal relationships outside the workplace and, according to Russell \& Bourke (2000), the link between productivity and good personal relationships is accepted. Good supportive relationships have a positive impact on wellbeing and health, which in turn has a positive impact on productivity, while lack of wellbeing has a negative effect on productivity.

\section{Friends}

Friendships are networks of resource and responsibility exchange, especially for women (Taylor et al, 2000). These networks can have positive spillover into the workplace as networks for achieving work outcomes. They are also a major source of emotional support, particularly for single people. Such support is an essential buffer against stress, including work-related stress. Friends are also a major source of reciprocal childcare provision (McPherson, 2003), which is a prerequisite of many women being able to do paid work. 
For New Zealand's new migrants, particularly those with English as a second language, relationships and friendships in the community and workplace are an important part of the integration and language development process that make a positive contribution to the workplace and New Zealand as a whole (Trlin et al, 1999).

Findings from EEO Trust survey (McPherson, 2004a) are consistent in each of these areas:

- Emotional support from my relationships helps me cope with work stress $71 \%$

- My social networks are often a useful resource for achieving work tasks/goals $32 \%$

- My friends are an important source of childcare $7 \%$

- Socialising with NZ friends helps me improve my English/understand NZ ways $2 \%$

\section{Workplace Issues that Affect Relationships, by Type of Worker}

Paid work has been increasingly encroaching on the time and energy needed for personal relationships. It does this in different ways, particularly for different types of workers (McPherson, 2004b).

\section{Issues for Those in Higher Paid and Professional-type Roles:}

- long work hours which may be part of the workplace cultural norm or undertaken by choice in order to meet discretionary goals such as education, holiday, house in certain area

- deadline pressure/intensity i.e. urgent demands of work

- travel - either frequent short-term travel or long-term commuting

- relocation through transfer or for career progression

- a workplace culture where work has priority over the rest of life

- intrusion of work on personal time through cell phones, email, on-call.

\section{Issues for Lower Paid, Manual, or Blue Collar} Workers:

- long hours to meet basic income needs, often through multiple part-time jobs

- $\quad$ shift work, irregular or unpredictable hours

- the need to relocate to find work while the partner stays behind because of cost of accommodation and location of support networks.

\section{Issues for Casual and Part-time Employees:}

- not being eligible for work-life policies only available to full-time permanent workers.

- unpredictable work times for those on call-in

\section{How Paid Work Impacts on Relationships}

Relationship quality is dependent on time together free of work interruptions or preoccupations - it is not just an issue of long hours, but of work demands, intensity, and role conflict. Relaxed leisure time together is necessary to establish intimacy, which in turn is a precursor to sexual intimacy (Pritchard, 2002; Russell and Bourke, 2000; Crouter et al, 2001; NZCTU, 2002; Weston et al, 2003).

Findings from the EEO Trust survey on paid work and relationships show paid work having a negative impact on both amount and quality of time spent with partners, and also with friends (Figure 3).

Figure 3

Negative impact of paid work on amount and quality of time with partners and friends

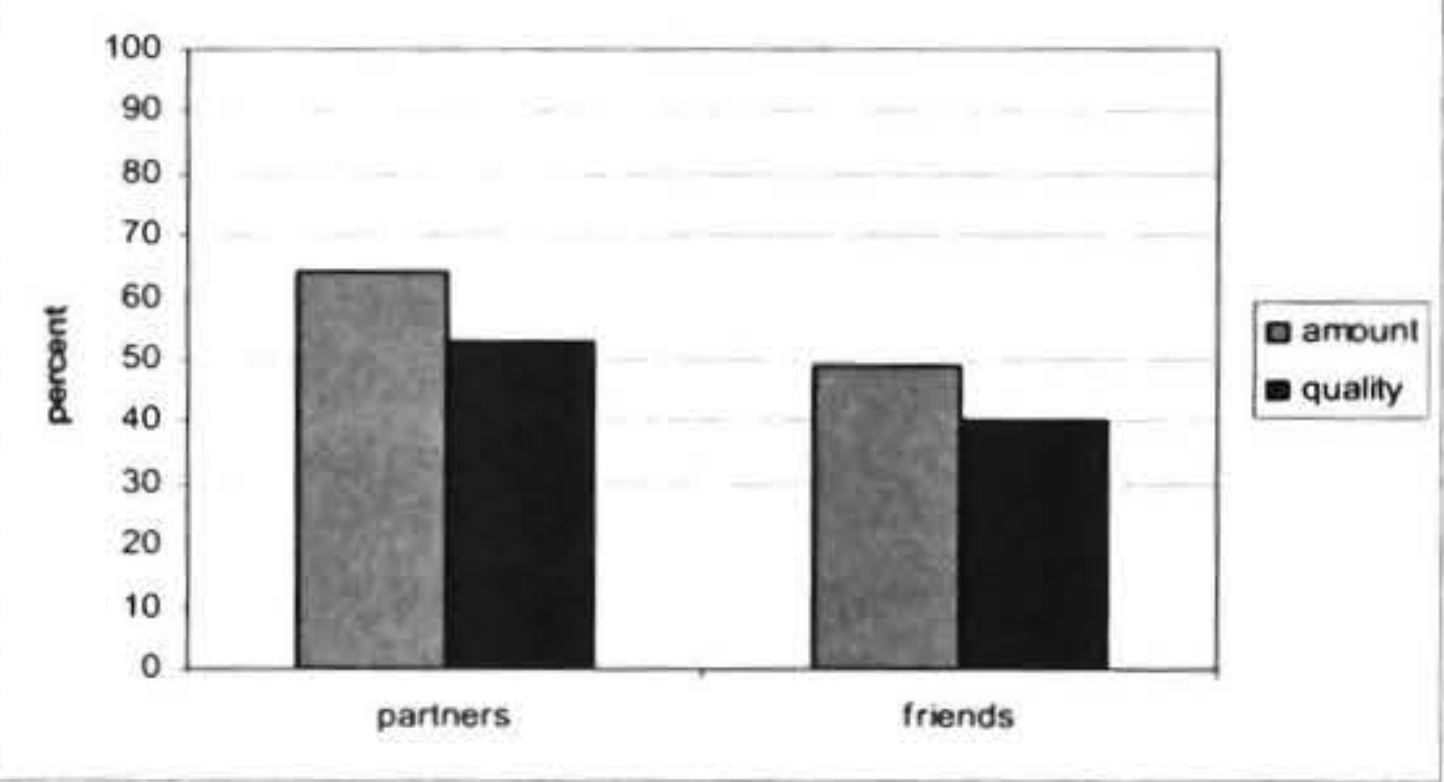

Partners' perceptions about long, unpredictable or irregular hours affect the impact of those hours on intimate relationships. If the long hours and consequent rewards are a shared goal, there may be no or little impact. Work issues are an issue for relationships if they are an issue for one partner, even if the other partner is happy about the work/life balance (Crouter et al, 2001; Russell \& Bourke, 2000; McMillan and O'Driscoll, 2003). This can be seen in the findings of the EEO Trust survey too (Figure 4).

Figure 4

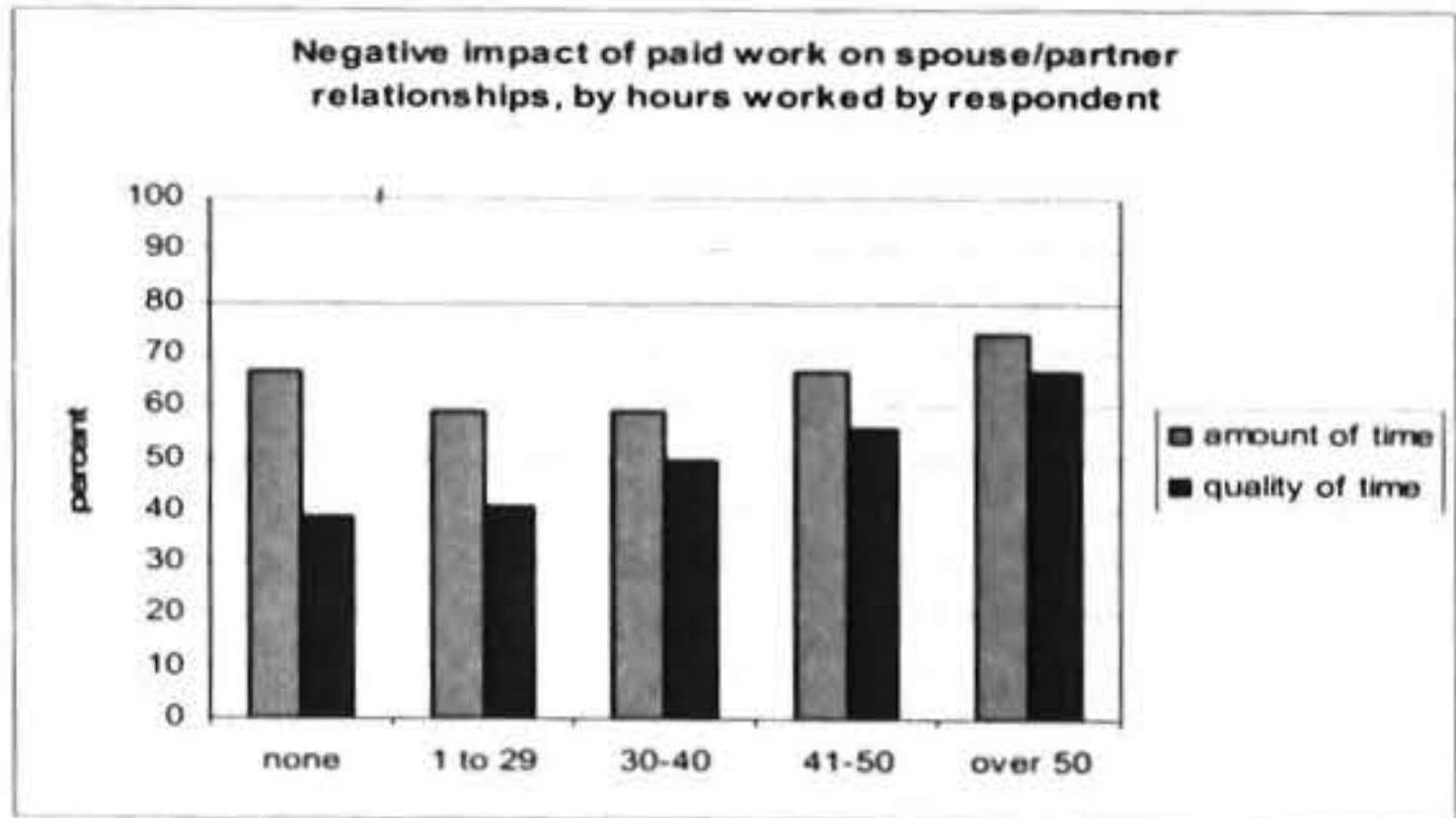


Long hours are particularly an issue if the husband's long hours result in the domestic load falling almost entirely on the woman, who is most likely doing paid work as well, and this leads to resentment and erodes the relationship (Pocock, 2001). It also limits the woman's career options in order to cope with the domestic load as well as paid work, and in order to accommodate her husband's career driven geographical moves.

The outcome is often a choice between the relationship or the job: divorce or a reduction of hours (Pocock et al, 2001). Most try to change the family rather than the job (Gautier, 2002). This often leaves the woman seriously disadvantaged economically as a result of putting her paid work in second place to her husband's paid work and their joint domestic needs (McPherson, 1995).

As one relationship counsellor key informant put it:

People feel increasingly high demands from the workplace leading to an issue of priorities and values with partner/family treated as optional and work as compulsory/first priority. Putting work demands ahead of family and partner needs results in conflict - people feel they have no choice but to meet work demands and this results in partners feeling undervalued, second best leads to resentment. (McPherson, 2004b).

In the words of another relationship counsellor key informant:

The work situation is perceived as inflexible, unchangeable, so it is the relationship that is neglected in order to meet work demands. To do otherwise would be to be judged negatively in the workplace (which seems to matter more than being judged negatively by partner!). (McPherson, 2004b).

Findings from the EEO Trust survey support this, with more than one in three respondents reporting they had had a relationship break-up where work was a contributing factor (Figure 5). However, there was also support for a similar proportion having put their relationship ahead of their work by turning down a job, promotion or transfer if it would impact badly on the relationship.

For those who had experienced a work-related relationship break-up, work pressure, exhaustion and stress were more likely to be a factor than long hours (Figure 6).

\section{Figure 5}

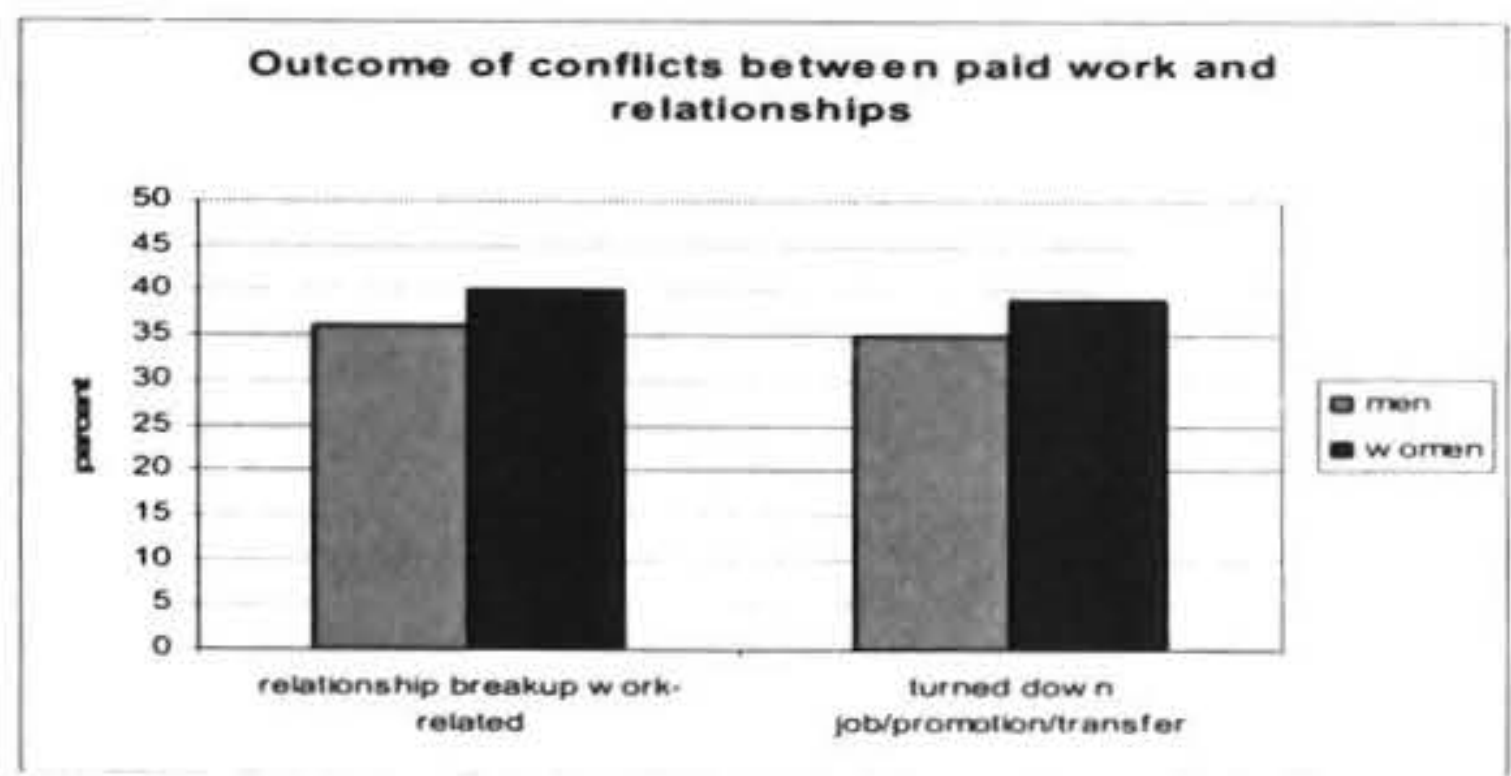

Figure 6

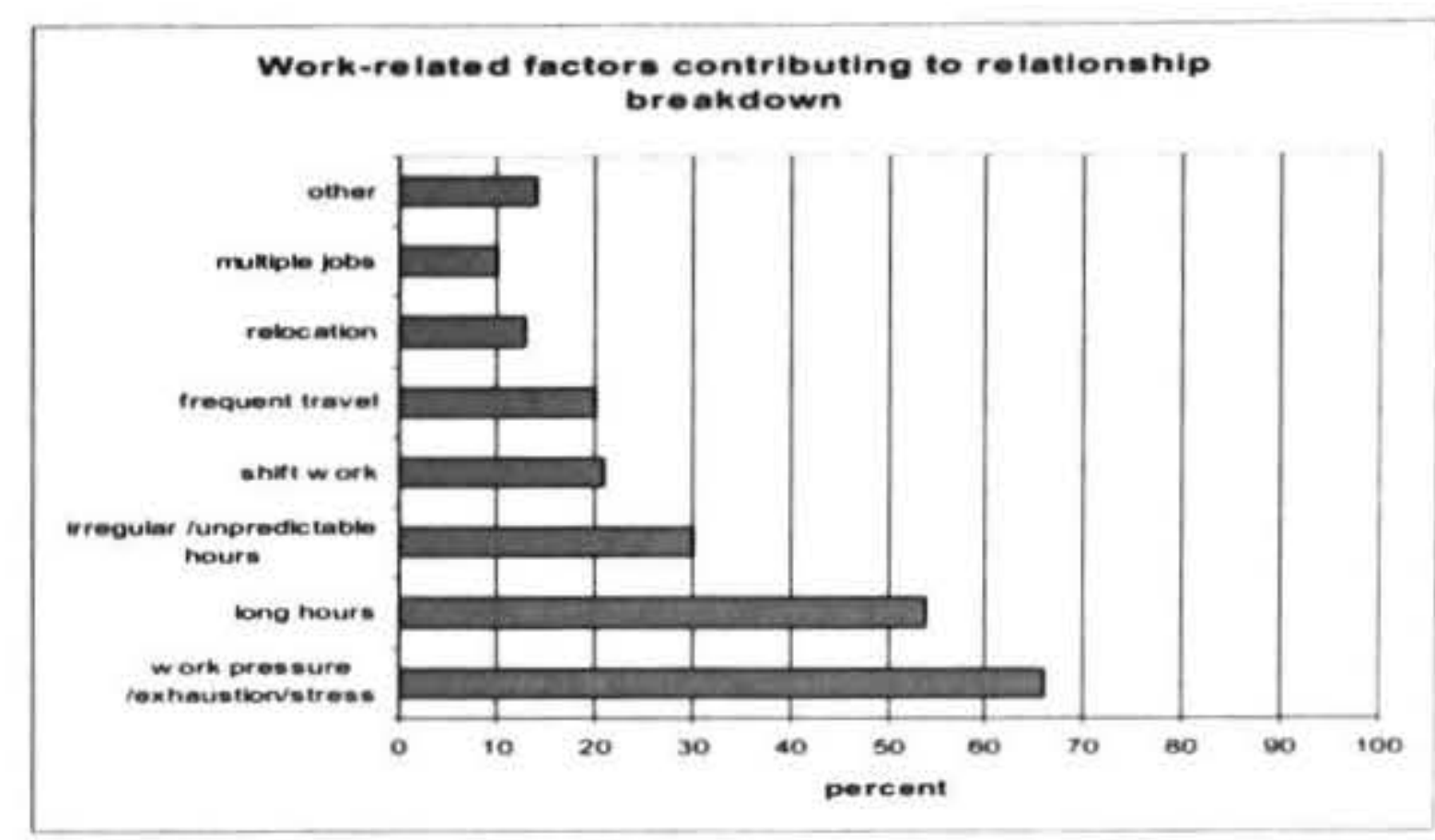

Long hours are sometimes worked by choice, but often it is the culture of long hours that leaves a worker with little choice.

It is very hard to get part-time work in my industry (IT) and managers continue to talk about staff who just want to work the 40hrs they signed up for as 'slackers'.

In my workplace it is easier to get promoted if you work longer hours and appear to be very focused on work and career objectives. Working just the basic hours doesn't display this commitment. While part-time or reduced hours are tolerated (particularly for managers) nonmanagement staff who want such options are seen as lacking motivation. (McPherson, 2004a).

Also consistent with the literature reviewed for this project (McPherson, 2004b) is the finding in the EEO Trust survey that it is not just long hours, but general work-related pressure, stress and exhaustion that impact on personal relationships.

Often too tired after a day's work to socialize. Tend to put off going out until the weekend which makes the weekends hectic and then I'm tired when Monday comes around as I haven't had much time to relax. (McPherson, 2004a)

The impacts of paid work on personal relationships vary depending on the type of work, the type of relationship and demographic factors such as gender, age and sexual orientation. Shiftworkers and casual workers find it difficult to have time with partner and attend social activities. Shiftworkers also have higher divorce rates than regular day workers (Johnston, 2002). These points were illustrated by comments in the EEO Trust survey.

My husband works a 40-hour week but sometimes has to work overtime for a few weeks and when this happens it puts a lot of stress on the relationship, but it gets back to normal afterwards. He is also required to be on call two weeks a month, which means we can't travel to see family nor can we socialise as easily as when he is not. However, he does get well compensated for it, but sometimes it seems like we would prefer not to get the extra money just for a little bit of freedom from his work.

Time to spend with partners family friends etc is usually determined by shift-work and call-backs to deal with crime and its associated problems. (McPherson, 2004a) 
Men and women can experience different specific impacts from an imbalance towards paid work. Women with work-life imbalance in favour of work are less likely than men to attract a partner prepared to tolerate or support such a lifestyle (Hewlett, 2002; Galinsky et al, 2003). Men who work long hours or whose work intrudes on personal time may be putting their relationships at risk if it affects couple time or the distribution of household labour, even if they don't mind the hours/intrusions themselves (Institute of Personnel and Development, 2001).

For young people, long hours make establishing and maintaining a relationship difficult. The insecurity of work today can make maintaining a relationship to the point of establishing a family difficult for young people too (Institute of Personnel and Development, 2001; Lewis and Brannen, 2000).

Gay and lesbian workers are disadvantaged if workplace policies exclude their partners from eligibility for benefits available to married partners, such as relocation arrangements. Such exclusion can limit their career advancement opportunities (Asquith, 1999).

Friendships are an important precursor to marital type relationships. Friends also often fill the role of partners or family for single people but may not be invited to workplace social events or be recognised in bereavement leave policies. But social life and friends are the first to slip off the list when there is work overload (NZCTU, 2002; UMR Research, 2003).

\section{Gender}

While there were some differences between men and women respondents in the EEO Trust survey, more striking was amount of similarity in their responses. Both men and women reported negative impacts of paid work on their relationships with friends and spouse/partners (Figure 7), both had put relationships ahead of job, promotion or transfer, and both had experienced similar levels of relationship breakdown where paid work was a contributing factor (McPherson, 2004a).

Where there were differences, they were generally not large. The largest percentage point difference was on the positive impact of emotional support from personal relationships on work performance: women $78 \%$, men $60 \%$. Both men and women would equally like more flexible work hours, shorter work hours, and less work intrusion into personal time through cell phones, meetings and travel.

\section{Age}

Differences by age group were not great in the EEO Trust survey, but did confirm some expected patterns. It is the $30-49$ years age group that is generally most affected by the impact of paid work on their personal relationships (McPherson, 2004a). This is the group whose time is also most likely to have to be divided into a parenting role, as well as a paid work and relationship role. As a result they are the age group most likely to want workplace initiatives to help them manage their work and relationship roles better.

Those aged under 30 are generally more similar to those aged 30-49 than to those aged 50+, suggesting in part changing attitudes and social trends. Unlike the 30-49 age group the under 30 s are less likely to be incorporating a parenting role as well. But they are concerned about the impact of paid work on the amount of time they can spend with their partner or friends, are more likely to want de facto partners recognised in workplace benefits that apply to married partners, and are more likely to want promotion to be available without having to relocate. These concerns reflect the more equal nature of spouse/partner relationships today than for previous generations.

Currently my partner and I are both working in excess of 50 hour per week and it is ruining our lives, we have very little time together and when we do we are both shattered from the amount for work we are doing. The odd occasion that we do get to see friends it's a struggle as we are both so tired and stressed that it is very rarely any fun anymore. We are both 24, we are too young for working such long hours for very very low salaries.

Those aged $50+$ are generally the least concerned or affected by the impact of paid work on relationships, except for the impact on quality of time with friends (Figure 8). They are less likely to think that their workplace needs to do anything to help support their personal relationships.

\section{Figure 7}

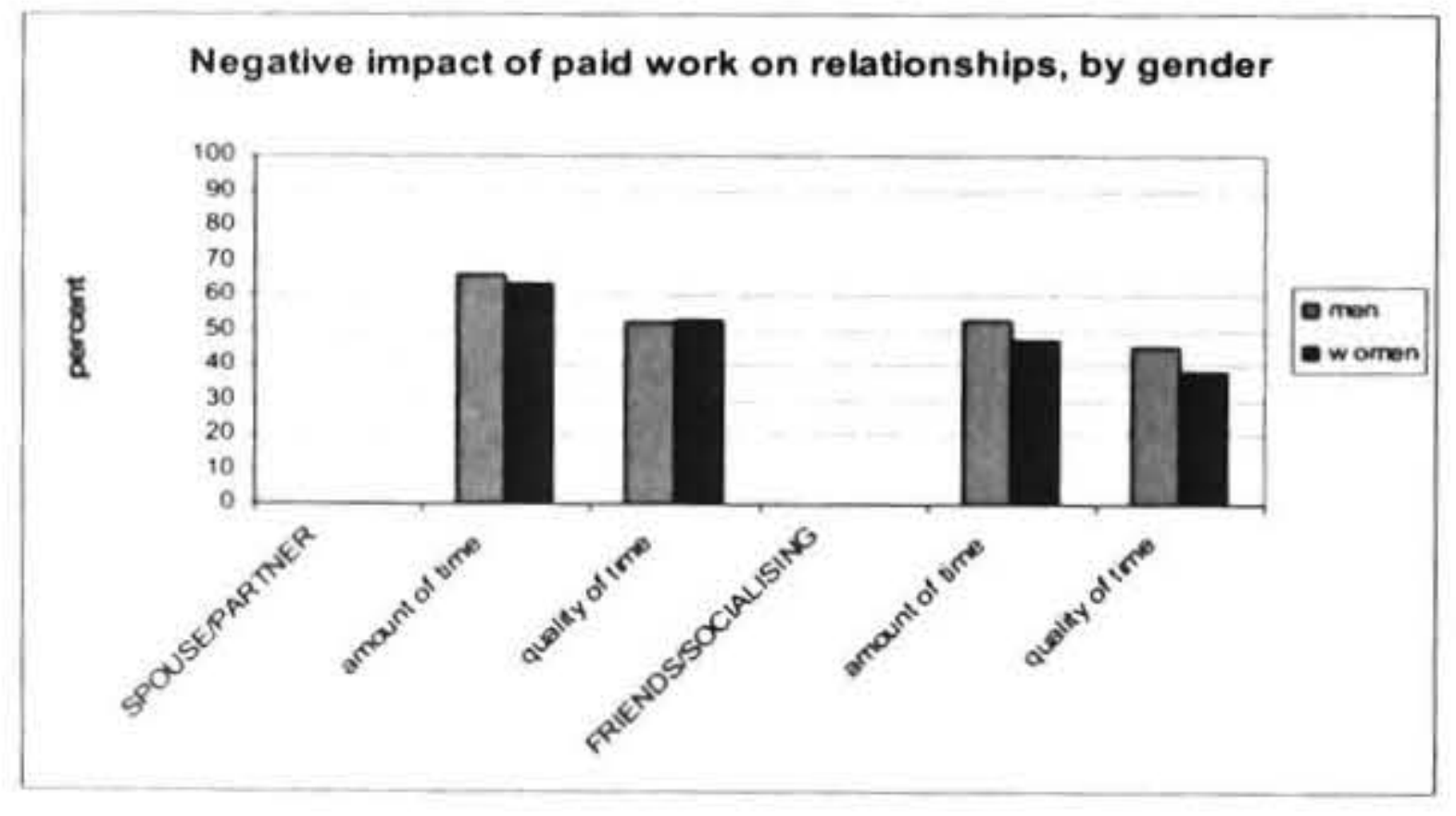

Figure 8

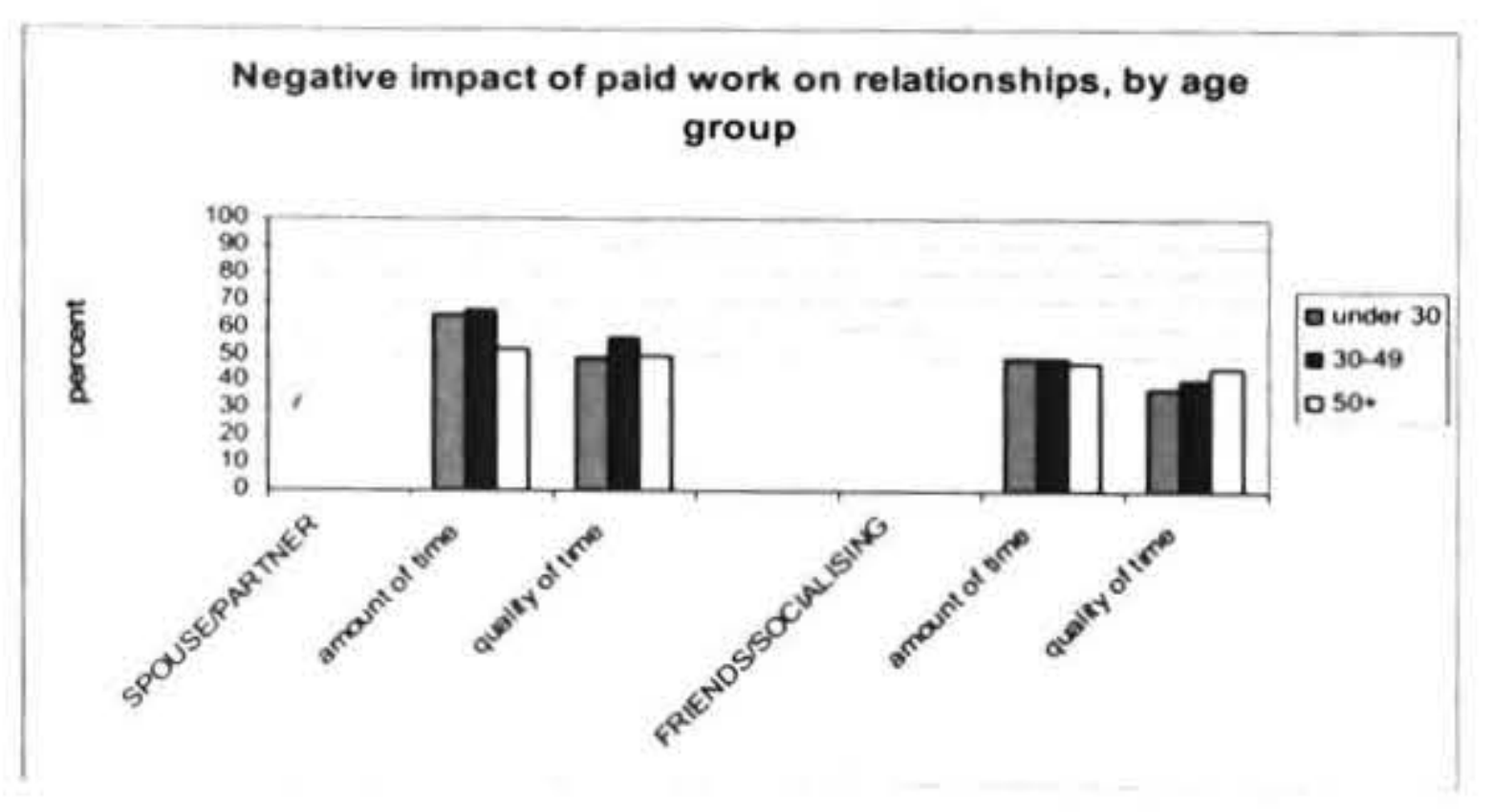


Potential Impacts on the Workplace of Workers not having Time for Good Personal Relationships

- Loss of productivity and negative impact on workplace safety as a result of stress, reduced sleep and preoccupation with relationship problems

- Increased absenteeism - absenteeism due to marital stress costs the US\$6.8 billion annually (Hill et al, 2001 cited in Pocock, 2001)

- Increased staff turnover - as employees seek work that has less impact on their relationships

- Ultimately fewer children, which means fewer workers and fewer consumers

\section{So Why Not go Back to the Breadwinner Model of Families/Relationships?}

A return to a breadwinner model of work and relationships would have negative implications for society, women and the labour market. Many women may opt for work over family rather than accept a full time home maker role, with the negative consequences for society as outlined earlier.

Such a disparate life for husband and wife can result in distancing effects (Pritchard, 2002) which can lead to relationship breakdown. In the event of relationship breakdown/divorce, women are left seriously disadvantaged economically as a result of putting their paid work in second place to their husband's paid work and their joint domestic needs (McPherson, 1995). This disadvantage is greatest for those who have been out of the paid work force completely and the longer they are out.

The current labour market could not withstand any further loss of skilled women; on the contrary, it increasingly needs to attract and retain them. As noted earlier, this is likely to make them more receptive to the need for workplace reform in order to allow this to happen.

We may see many highly trained young New Zealand women failing to reach their potential in their chosen fields because they have chosen to take time to care for their children - with a consequent loss of the skills in which they and the society have made a heavy investment. Where will that leave the 'knowledge society'? (Sceats, 2003:169)

Hakim's (2003) research in the UK found women fell into three categories:

- Work centred $\quad 20 \%$

- Home centred $20 \%$

- Adaptive $60 \%$

The majority are adaptive; they want to combine work and motherhood. Their ability to do so depends on workplace and government policies and initiatives to enable them to do so.

\section{Solutions: How Workplaces can Support Healthy Relationships}

- Implement and model policies conducive to positive personal relationships

- Consult staff to identify what issues are relevant for them

- Change workplace culture - denormalise long hours and priority of work over personal relationships

- Flexibility of hours

- Counselling options available

- Consider the need for and impact of travel and relocation

- Consider the needs of dual career couples

- Greater consultation and flexibility for shiftworkers

- Consider the impacts of non-standard work on personal relationships and take steps to improve

- Improve range of leave conditions to cover wider range of personal circumstances

- Consider the needs of all types of close personal relationships e.g. gay/lesbian, singles

(McPherson, 2004b)

Table 2 outlines preferred workplace initiatives from the EEO Trust survey, according to gender and age.

\section{Role of Government}

Government also has a role to play:

- As an employer role model in the implementation of work-life balance policies and programmes that are relationship friendly as well as family-friendly.

- Through policy/legislation around hours of work required for full-time status and conditions.

- To educate and inform employers and employees of the benefits of considering relationship factors in work-life initiatives, and the ways to implement and promote relationship enhancing policies and programmes.

\section{Further Research}

The major gap in New Zealand is a nationally representative sample survey on these issues which will be partially filled by the forthcoming Ministry of Social Development study on Work, Family and Parenting. But there is also room for smaller scale research on specific aspects and groups for example, Maori, gay/lesbian, and within the predominantly small businesses that predominate the New Zealand business sector. 
Table 2: Preferred Workplace Initiatives to Support Employees having Good Personal Relationships

\begin{tabular}{|c|c|c|c|c|c|c|}
\hline & Total & Women & Men & Under 30 & $30-49$ & 50 and over \\
\hline & \multicolumn{6}{|c|}{$\%$} \\
\hline Provide flexible work hours & 55 & 54 & 56 & 55 & 58 & 44 \\
\hline $\begin{array}{l}\text { Train managers in awareness of work practices that } \\
\text { impact on relationships (both positively and } \\
\text { negatively) }\end{array}$ & 41 & 43 & 38 & 32 & 48 & 38 \\
\hline Provide a secure, permanent job & 37 & 35 & 41 & 35 & 38 & 40 \\
\hline $\begin{array}{l}\text { Consult staff about work practices that would } \\
\text { minimise work related problems affecting personal } \\
\text { relationships. }\end{array}$ & 33 & 36 & 29 & 28 & 38 & 33 \\
\hline $\begin{array}{l}\text { Enable staff to work fewer hours as a full-time } \\
\text { worker }\end{array}$ & 30 & 30 & 32 & 27 & 33 & 28 \\
\hline Make promotion available without relocation & 29 & 27 & 33 & 33 & 29 & 18 \\
\hline Hold meetings in core work hours only & 30 & 31 & 29 & 27 & 32 & 28 \\
\hline $\begin{array}{l}\text { Restrict work related travel to work time e.g. not } \\
\text { during personal time such as Sundays in order to be } \\
\text { at destination to start work on Monday }\end{array}$ & 20 & 20 & 21 & 19 & 23 & 13 \\
\hline $\begin{array}{l}\text { Provide an Employee Assistance Programme or time } \\
\text { to attend counselling for relationship problems }\end{array}$ & 19 & 22 & 14 & 18 & 22 & 14 \\
\hline Include friends in work related social events & 19 & 21 & 15 & 25 & 16 & 11 \\
\hline $\begin{array}{l}\text { Include de facto partners (including same sex) as } \\
\text { eligible for married partners' benefits }\end{array}$ & 18 & 21 & 12 & 23 & 16 & 8 \\
\hline $\begin{array}{l}\text { Limit or prohibit cell phone and email contact to staff } \\
\text { during personal time such as at evenings, weekends } \\
\text { and holidays }\end{array}$ & 18 & 17 & 19 & 19 & 20 & 6 \\
\hline Its fine as it is & 17 & 19 & 15 & 18 & 16 & 22 \\
\hline Allow staff to work part-time in their current position & 16 & 17 & 16 & 13 & 19 & 13 \\
\hline $\begin{array}{l}\text { Ensure that as a shift worker } I \text { have adequate evening } \\
\text { and weekend time for socialising }\end{array}$ & 10 & 9 & 13 & 10 & 11 & 7 \\
\hline Provide domestic violence policies and programmes & 5 & 6 & 3 & 4 & 6 & 3 \\
\hline None of these would help & 3 & 3 & 3 & 3 & 2 & 4 \\
\hline
\end{tabular}

\section{Conclusion}

This paper has drawn on a wide range of primary and secondary sources, both New Zealand and international, that provide information to enhance our understanding of the impact paid work has on personal relationships, and the impact personal relationships have on paid work. The EEO Trust on-line survey provides local data at age and gender level, but is not based on a random sample and therefore not generalisable to the total New Zealand population. However, these findings are complemented by nationally representative sample research from similar societics such as Australia and the UK that confirm that work-life balance is an issue for maintaining good relationships for a significant proportion of the population, if not as high as the EEO Trust survey findings.

The findings also show that some of our sample population, both men and women, place a higher priority on their relationships than their paid work. This was more likely among those aged 30-49, suggesting an increasing trend, as those aged less than 30 likely to exhibit similar behaviour as they move through the life course. Those aged 50 and over are more likely to have raised their families in a time when the man was likely to be the only or main breadwinner, with his partner taking care of domestic duties. This is not the case with the two younger groups, and employers need to be aware of changing social mores and how they impact on workplace and career decisions for both men and women in the middle and younger generations.

Finally, this paper presents an argument for the importance of these interactions for society and political economy and recommendations, based on both overseas and New Zealand research, for the role of workplaces and government in improving the interaction between paid work and relationships to reap the benefits of good personal relationships and minimise the negative consequences of poor personal relationships for individuals, families, the workplace and society. 


\section{Notes}

1. Long hours is defined in most studies as 45 or $48+$ hours per week.

2. A forthcoming report on Work, Family and Parenting from the Ministry of Social Development, based on a random sample survey, contains some overlapping data that is consistent with and almost identical to the findings of the online EEO Trust survey.

\section{References}

Asquith, N.L. 1999: Sexuality at work: a study of lesbian's workplace experiences. New Zealand Journal of Industrial Relations, 24(1):1-19.

Crouter, A.C., Bumpus, M.F., Head, M.R. \& McHale, S.M. (2001). Implications of overwork and overload for the quality of men's family relationships. Journal of Marriage and the Family, 63(May):404-416.

Department of Labour (2003). Skills in the Labour Market - November 2003.

Gautier, A. (2002). Paying the price - the high cost of executive success. Management (July): 34-37.

Harker, L. (2003). Work-life debate at a crossroads: perspectives in the United Kingdom. In Diverse Cultural Perspectives of Work and Family, Sloan Work and Family Research Network, Boston College, www.bc.edu/wfnetwork

Horin, A. (2003). Jobless, single and male. Sydney Morning Herald, 2 October 2003.

Institute of Personnel and Development (1999). Living to work? IPD survey report. Institute of Personnel and Development, London.

Johnston, F. (2002). Living with shift-work - practical information to help you. $2^{\text {nd }}$ Annual Rostering and Shift-work Conference, Employer \& Manufacturers Assn Northern.

Johnston, I. (2003). Relationships Indicators Survey 2003, Relationships Australia (National), December 2003. www.ra.asn.au

Lewis, S. 7 Brannen, J. 2000: Forever young? Generation X's views on gender, work and family issues. In Family Business, H. Wilkinson, ed., Demos Collection 15:120-126.

Matz, C. (2003). Work/life issues span the globe. In Diverse Cultural Perspectives of Work and Family, Sloan Work and Family Research Network, Boston College, www.bc.edu/wfnetwork

McMillan, L. H. W., \& O'Driscoll, M. P. (2003). Workaholism, stress and relationships: Where does the difference lie? British Journal of Guidance \& Counselling (in press).
McPherson, M. (2004a). Report of Findings from EEO Trust Relationships and Paid Work Survey. EEO Trust, Auckland.

McPherson, M. (2004b). Paid Work and Personal Relationships. A report incorporating material from a review of New Zealand and international literature and research, key informant interviews with three New Zealand relationship counsellors, an on-line EEO Trust survey, analysis of New Zealand statistical data, and New Zealand examples of workplace initiatives from EEO Trust Work \& Life Awards entrants. EEO Trust, Auckland.

McPherson, M. (2003). The Nature and Role of the Extended Family in New Zealand, Family Studies Monograph No.2, Social Policy Research Centre, Massey University, Palmerston North.

McPherson, M.J. (1995). Divorce in New Zealand. Social Policy Research Centre, Massey University, Palmerston North.

New Zealand Council of Trade Unions (2002). Thirty Families. Interim report of the thirty families project: the impact of work hours on New Zealand workers and their families. A report commissioned by the New Zealand Council of Trade Unions, 2002.

Pocock, B. (2001). The Effect of Long Hours on Family and Community Life. A Survey of Existing Literature. A report for the Queensland Department of Industrial Relations. Centre for Labour Research, Adelaide University.

Pritchard, R. (2002). Love in the Real World. Starting and Keeping Close Relationships, Penguin, Auckland.

Russell, G. (2003). Fathering in Families. Paper presented at Strengthening Family Relationships Conference, Victoria University of Wellington (paper to become available on Ministry of Social Development SPEaR website. www.spear.govt .nz).

Russell, G. \& Bourke, J. (2000). Let's get personal. Missing the intimate relationships connection. In Family Business, H. Wilkinson, ed., Demos Collection 15:111-119.

Saunders, A. (2004). Struggle over skills shortage. The Independent 29/01/2004. http://xtramsn.co.nz/ business/

Sceats, J. (2003). The impossible dream: motherhood and a career? Population and Social Policy. Special issue of New Zealand Population Review, 29(1), May 2003. Population Association of New Zealand, Wellington: 155-170.

Statistics New Zealand, 2004: Demographic Trends 2003. 
Statistics New Zealand, 2003: Labour Market Statistics 2003.

Statistics New Zealand, 2001: 2001 Census Snapshot 2 - Who has access to the internet? - Media Release. http://www.statistics.govt.nz/domino/ external/pasfull/pasfull.nsf

Straw, E. (2000). Getting the relationship right. How home and workplace can learn from each other. In Family Business, H. Wilkinson, ed., Demos Collection 15:134-140.

Taylor, S.E., Klein, L.C., Lewis, B.P., Gruenewald, T.L., Gurung, R.A.R. \& Updegraff, J.A. (2000). Biobehavioral responses to stress in females: tendand-befriend, not fight-or-flight. Psychological Review 107(3):411-429.
Trlin, A., Henderson, A., \& North, N. (1999). Effects of unemployment among skilled immigrants from India.

New Zealand Population Review, 25(1\&2), 99-117.

UMR Research (2003). Perceptions and attitudes towards work-life balance in New Zealand. A qualitative study. Department of Labour, Wellington.

Weston, R., Gray, M., Qu, L. \& Stanton, D. (2003). The impact of long working hours on employed fathers and their families. Revised version of paper presented to the Australian Social Policy Conference, Sydney, 2003. Australian Institute of Family Studies. 